\title{
EXHAUSTION OF REMEDIES IN PRIVATE, VOLUNTARY ASSOCIATIONS
}

PrIvate, voluntary associations have become increasingly important in American political and economic society. ${ }^{1}$ Labor unions, trade and professional associations and various other "private" groups have attained a quasi-governmental status in their economic spheres of operation, ${ }^{2}$ and have also become major factors in local and national political arenas. ${ }^{3}$ Rights of membership in

1. In 1949, there were at least 4,000 national trade, professional and civic associations in the United States. U.S. Dep't of Commerce, National Associations of the United States vii (1949). At the local level, there were 12,000 trade associations, 4,000 chambers of commerce, 70,000 labor unions and 15,000 civic service groups. Id. at viii. Fraternal organizations reported more than seventeen million members. Id. at 483 . In 1951 the membership figure for trade unions was $15,300,000$; in 1940 it was $8,500,000$; in 1930, 3,392,800. Peterson, American labor Unions 62 (rev. ed. 1952). The new AFL-CIO will have fifteen million members. N.Y. Times, Dec. 3, 1955, p. 1, col. 1. Total church membership in 1953 was $94,842,845$. A GutDe to the ReLigions of Adrerrca 196 (Rosten ed. 1955).

Mrost professional men are members of an association. The American Medical Association in 1953 claimed a membership of more than 140,000. Practically all doctors belong to a local society, and nearly all societies are affiliated with the national Association. Comment, 63 YALE L.J. 93S, 939 (1954). In 1954, the American Bar Association claimed a membership of more than 52,000. ANserican Bar Assoctation, 79TH ANNuAL Report 151 (1954).

2. Private voluntary associations operate in the social and political, as well as economic spheres. For example, there are political parties, both local and national, fraternal organizations, churches, civic groups, and special interest groups. An example of the latter is the American Legion, which has a membership of more than three million. U.S. DEP'T of Comirerce, National Associations of the United States 534 (1949). See, generally, Kex, Politics, Parties and Pressure Groups (2d ed. 1948).

3. Legislation has added greatly to the economic power and leverage of certain associations. Organized medicine is able to maintain a quasi-governmental control over medical affairs, because important judicial and regulatory functions have been delegated to it by the states. Comment, 63 YAlE L.J. 937, 959 (1954). By allowing monopolies in particular fields, legislation has forced the prospective practitioner to conform with rules established by those who generally set the standards for entry and disciplinary expulsion. See, e.g., Report of the Standing Connittee on Unauthorized Practice of Law, AMERICAN BAR Assoctation, 79tr Annual Report 137, 138 (1954).

Labor unions especially have been fortified by legislation. In order to bargain for his wages, a worker must by law speak only through the union, if it is certified. The National Labor Relations Act $\$ 9$ (a), 49 StAт. 453 (1935), as amended, 29 U.S.C. $\$ 159$ (a) (1952), and the Railway Labor Act $\S 2,44$ STAт. 577 (1926), 45 U.S.C. $\$ 152$ (1952), allow a majority to select a bargaining representative. Once certified, the union is the sole representative for all workers in the unit, whether members or not. Aaron \& Komaroff, Statutory Regulation of Internal Union Affairs - I, 44 ILL. L. Rev. 438, 439 (1949) ; see Griffith, Labor Unions-Political Organizations for Monopolistic Action, 1 LAB. L.J. 689 (1950).

For other examples of associations with governmental functions, see Otis \& $C_{0}$. v. National Ass'n of Securities Dealers, 84 F. Supp. 395 (D.D.C. 1949) (association given 
these associations have become virtually indispensable to the economic survival of the worker, ${ }^{4}$ businessman ${ }^{5}$ and professional practitioner. ${ }^{6}$ Yet, even though the societal role of associations has changed, the law governing the relations between association and member often has not. ${ }^{7}$ In particular, one legal rule which has proved anachronistic in its application is the requirement that an aggrieved member of an association must exhaust his remedies within the association before bringing his grievances to the courts.

The constitutions and bylaws of private associations generally establish internal, semi-judicial procedures by which association officials are empowered to adjudicate disputes between member and association. ${ }^{8}$ The association usually provides certain benefits for its members $;^{9}$ and, in order to enforce its

judicial powers by federal law, which ca-ordinates its activities with the SEC); Swital v. Real Estate Comm'r, 116 Cal. App. 2d 677, 254 P.2d 587 (1953) (interrelationship between realty association and the California Real Estate Commission).

4. See discussion in Local 104, Int'1 Brotherhood of Boilermakers v. International Brotherhood of Boilermakers, 33 Wash. 2d 1, 45, 203 P.2d 1019, 1045 (1949); Rose, The Right To Work, 1 LAB. L.J. 293 (1950).

5. See Otis \& Co. v. National Ass'n of Securities Dealers, 84 F. Supp. 395 (D.D.C. 1949) ; Swital v. Real Estate Comm'r, 116 Cal. App. 2d 677, 254 P.2d 587 (1953) ; State Rubbish Collectors Ass'n v. Siliznoff, 38 Cal. 2d 330, 240 P.2d 282 (1952).

6. See Comment, 63 Y ALE L.J. 937 (1954); cf. Blenko v. Schmeltz, 362 Pa. 365, 67 A.2d 99 (1949) (patent law association); Brown v. Harris County Medical Soc'y, 194 S.W. 1179 (Tex. Civ. App. 1917).

7. For general review of association law, see Chafee, The Internal Affairs of Associations Not for Profit, 43 HaRv. L. REv. 993, 994 (1930), discussing association law established in Dawkins v. Antrobus, 17 Ch. D. 615 (1881), a case which is still good law today, Chafee, supra, at 1014.

8. For description of union procedures, see Summers, Disciplinary Procedures of Unions, 4 IND. \& LAB. ReL. Rev. 15 (1950) ; Taft, Judicial Procedure in Labor Unions, 59 Q.J. Econ. 370 (1945). The typical union procedure involves a trial or tendering of claim on the local level, where a committee of the membership passes on the issues. Upon adverse vote of the local membership, the aggrieved party may appeal to an intermediate tribunal ; then to the national or central appellate body; and, finally, to the general convention. Church systems are often similar. In the Roman Catholic Church, for example, the appeal is to the parish priest, the bishop, the Archbishop, the Apostolic Delegate in Washington, and, finally, to the Pope in Rome. See 2 U.S. Dep'T of Commerce, Burenu of THE Census, Religious Bodres : 1936, pt. 2, at 1546-50 (1941). For the appeal system in the American Medical Association, see Comment, 63 Y ALE L.J. 937, 949-50 (1954).

9. E.g., unions have traditionally provided life insurance, pensions and disability benefit plans for their members. Latrmer, Trade Union Pension Systems passim (1932). Generally, beneficial and fraternal beneficiary societies exist for the purpose of insuring their members. 1 Bacon, LIFE and Accident Insurance $\S 2$ (4th ed. 1917) (hereinafter cited as BACON). Many nonmonetary benefits are similarly important for the member's welfare. The union processes grievances, Marchitto v. Central R.R., 9 N.J. 456, 88 A.2d 851 (1952) (suit for damages for failure of union to process grievance properly), and often controls seniority rights, Walker v. Pennsylvania-Reading Seashore Lines, 142 N.J. Eq. 588, 61 A.2d 453 (Ch. 1948) (dispute between local and national union over use of seniority system). Trade associations provide markets and trade services. White $v$. Brownell, 2 Daly 329 (N.Y. Sup. Ct. 1868) (marketplace for sale of securities). The American Medical Association controls hospital facilities, and often denies their use to nonmembers. Comment, 63 Y ALE L.J. 937, 952 (1954). 
policies and attain its objectives, the association must have the power to control its membership by excluding, expelling and disciplining deviants. ${ }^{10}$ The performance of these and other functions gives rise to disputes between the association and some of its members. ${ }^{11}$ These disputes are initially adjudicated by officials of a local branch of the association. If their decision is adverse to the member, he is generally able to appeal to a higher level within the organization's hierarchy. ${ }^{12}$ If the association's highest tribunal denies his claim, he is ordinarily permitted to bring his claim to court. ${ }^{13}$ Most association members confine their litigation to the internal system provided by the association. ${ }^{14}$

10. See Summers, Disciplinary Powers of Unions, 3 INp. \& LAB. Rer. Rev. 483 (1950); Aarerican Civil Liberties Union, Dearccracy in Trade Unions 27 (1943).

11. Other types of disputes also occur. Members will sometimes attempt to enjoin the association from favoring other members, Harris v. Missouri Pac. R.R., 1 F. Supp. 946 (E.D. Ill. 1931) ; rival factions within the association may fight for possession of its property, Watson v. Jones, 80 U.S. (13 Wall.) 679 (1871); a local group may fight an affiliate, Greenwood v. Building Trades Council, AFL, 71 Cal. App. 159, 233 Pac. 823 (1925). The group may sue a member to prevent his undesirable actions. Horst v. Traudt, 43 Colo. 445, $96 \mathrm{Pac}$. 259 (1908). Furthermore, one member may sue to force the group to discipline another member, Terell v. Knights of Ku Klux Klan, 155 Ga. 135, 116 S.E. 289 (1923); to correct internal election abuses, Leahigh v. Beyer, 116 N.E.2d 458 (Ohio C.P. 1953) ; to gain back a paying job within the association, Bogadek v. Butkovic, $336 \mathrm{~Pa} .284,9$ A.2d 388 (1939); or to obtain damages for defamation of character caused by the association's actions, Preveden v. Croatian Fraternal Union, 120 F. Supp. 33 (W.D. Pa. 1954).

12. See note 8 supra. The number of appellate levels usually varies directly with the size and complexity of the association. Small, informal groups have few, if any, appeals. E.g., Jeffersonian Club v. Waugh, 217 S.W.2d 103 (Tex. Civ. App. 1949) (women's club). As the membership increases, and interests become more important, the possibility of an extensive appeal system increases. E.g., North Dakota v. North Central Ass'n of Colleges and Secondary Schools, 99 F.2d 697 (7th Cir. 1938).

13. Some associations have attempted to contract away the member's right to sue by including in the bylaws proscriptions against the member going to court under any circumstances. The courts have consistently voided these provisions, characterizing them as attempts to oust the courts of jurisdiction. Kelly v. Trimont Lodge, 154 N.C. 97,69 S.E. 764 (1910) ; Baltimore \& O.R.R. v. Stankard, 56 Ohio St. 224, 46 N.E. 577 (1897); Bauer v. Samson Lodge, Knights of Pythias, 102 Ind. 262, 271, 1 N.E. 571, 576 (1885) (dictum). Courts will not entertain even these disputes however, unless "property" is involved. See notes 103-10 infra and accompanying text.

14. The following data is drawn from a questionnaire on union discipline, sent by the Yale Law Journal to every national union listed in U.S. BUREAU of LABOR STATrSTICS, DIRECTORY of LABOR UnIONS (Supp. 1954). The reporting unions claimed membership of $1,740,000$, representing about $10 \%$ of organized labor. Of persons disciplined by these unions during the period from 1951-1953, only $0.1 \%$ appealed directly to the courts. The unions had, on the average, a total of approximately 9,500 discipline cases per year. Most were purely administrative; only 47 members appealed to tribunals within the union. Of the 47 cases, 12 were decided in favor of the member, 35 in favor of the union. Only 5 of the 35 members who lost continued the appeal to the courts. Questionnaire dated Nov. 20,1954, on file in Yale Law Library. See also Summers, Disciplinary Powers of Unions, 3 IND. \& LAB. REL. REv. 483, 487 (1950), who found only 218 court decisions reported for the 60 years from 1890 to 1950 . 
A few members, however, attempt to short-circuit the internal appellate system; they bring their grievances to court before they have been submitted to the association's highest appellate board. Most courts refuse to hear these disputes because the member has failed to "exhaust" his intra-association remedies. ${ }^{15}$

The exhaustion rule has been subjected to verbal attack by commentators and physical attack by the courts. Many courts, in order to avoid an apparently unjust result, have developed sweeping exceptions to the rule which are broad enough to destroy its effectiveness. ${ }^{16}$ The breadth of the exceptions has generally varied directly with the economic importance of the association. ${ }^{17}$ In view of these sweeping exceptions, some commentators have concluded that the rule is a sham which the courts may avoid at will. ${ }^{18}$ Yet the rule is firmly established in American law, ${ }^{19}$ and the fact is that a substantial number of plaintiffs still lose actions against private associations because of failure to satisfy the exhaustion rule. ${ }^{20}$

This comment will argue that the exhaustion rule is fundamentally sound. It will examine the doctrinal rationale used to justify the rule, which is unsound, ${ }^{21}$ and offer in its stead a more satisfactory policy justification..$^{22}$ It will then examine, in the light of the policy justification, the propriety of various exceptions to the rule $;^{23}$ and will suggest a reformulation of basic exceptions in order more fully to effectuate the policies proposed without prejudicing the interests of aggrieved members. ${ }^{24}$ Finally, it will discuss the judicial procedures most appropriate to the determination whether plaintiff has

15. See note 19 infra.

16. See notes 52-75 infra and accompanying text.

17. Compare the rigid exhaustion requirement in a case involving a mystic society, Costa v. La Luna Servante, 255 Ala. 6, 49 So. 2d 672 (1950), with the broad exhaustion exception allowed by the same court in a case involving a union, Lucal 4, Nat'l Organization Masters v. Brown, 258 Ala. 18, 61. So. $2 \mathrm{~d} 93$ (1952). Cf. Chafee, supra note 7, at $1021-22$.

18. See Vorenberg, Exhaustion of Intraunion Remedies, 2 LAB. L.J. 487, 493 (1951); Comment, 22 U. Crir. L. Rev. 694, 698-99 (1955).

19. E.g., Costa v. La Luna Servante, 255 Ala. 6, 49 So. $2 \mathrm{~d} 672$ (1950) ; Royce v. International Union of Operating Engineers, 29 L.R.R.M. 2416 (Cal. Super. Ct. 1952) ; Zeidler v. Knights of Columbus, 172 Kan. 557, 241 P.2d 761 (1952) ; Irwin v. Lorio, 169 La. 1090, 126 So. 669 (1930) ; Thorn v. Foy, 328 Mass. 337, 103 N.E.2d 416 (1952) ; Mayo v. Great Lakes Greyhound Lines, Inc., 333 Mich. 205, 52 N.W.2d 665 (1952) ; Siena v. Grand Lodge, 11 N.J. Super. 507, 78 A.2d 610 (App. Div. 1951) ; Lafond v. Deems, 81 N.Y. 507, \& Abb. App. Dec. 344 (1880) ; Dakchoylous v. Ernst, 282 App. Div. 1101, 126 N.Y.S.2d 534 (3d Dep't 1953) ; Bogadek v. Butkovic, 336 Pa. 284, 9 A.2d 388 (1939); Minch v. Local 370, Int'l Union of Operating Engineers, 44 Wash. 2d 15, 265 P.2d 286 (1953).

20. Forty-two exhaustion cases were reported from 1945 to 1955 . Plaintiffs were required to exhaust in twenty-two of the cases, while exceptions were granted in twenty cases. This seems to have been the approximate breakdown of exhaustion cases since 1900 .

21. See notes $27-41$ infra and accompanying text.

22. See notes $42-51$ infra and accompanying text.

23. See notes $52-80$ infra and accompanying text.

24. See notes 81-88 infra and accompanying text. 
exhausted his remedies, ${ }^{25}$ and the types of persons, issues and associations to which the exhaustion rule should be applied. ${ }^{26}$

\section{The Policy Bases of the Exhaustion Rule}

The courts have recognized only one reason for the exhaustion rule. The reason, which has varied little since its introduction into American law nearly 100 years ago, is that the member, by voluntarily joining the organization, binds himself contractually to abide by its constitution and bylaws. ${ }^{27}$ Thus, where the constitution or bylaws require the member to bring his grievances to intra-association bodies before going to the courts, compliance with those requirements is a condition precedent to any other action which may be brought on the contract of membership. ${ }^{28}$ And until the condition is performed, no cause of action will lie.

Courts should not, and most do not, follow the contract rationale in all cases. If the contract theory were strictly applied, the courts would require the member to carry an appeal to an association convention meeting four years in the future if the bylaws so provided : the courts have uniformly refused to require compliance with such conditions. ${ }^{29}$ If the contract theory were strictly applied, the exhaustion rule would not bind nonmembers; yet the majority rule is that

25. See notes $88-96$ infra and accompanying text.

26. See notes $97-110$ infra and accompanying text.

27. The first reported case was White v. Brownell, 2 Daly 329 (N.Y. Sup. Ct. 1868). The court held that a member of a stock brokers' association, suing to enjoin the group from depriving him of rights of membership, was contractually bound by the association's constitution and bylaws to exhaust his remedies before coming to court. This remains the rule. See 4 AMr. Jur., Associations and Clubs $\$ 31$ (Supp. 1955) ; 87 C.J.S., Trade Unions $\$ 49$ (Supp. 1955) ; Comment, 22 U. CHI. L. Rev. 694, 698 (1955). Courts do not always mention the contract doctrine when denying relief, however. Waldman v. Ladisky, 101 N.Y.S.2d 87 (Sup. Ct. 1950) ; Screwmen's Benevolent Ass'n v. Benson, 76 Tex. 552, 13 S.W. 379 (1890) ; Lafond v. Deems, 81 N.Y. 507, 8 Abb. App. Dec. 344 (1880).

It is interesting to note that an earlier English case, Carlen v. Drury, 1 Ves. \& B. 154, 35 Eng. Rep. 61 (Ch. 1812), applied another theory to a similar situation. Members were suing in equity to dissolve a joint business concern. Dissolution was attainable by recourse to a general vote of the membership; this procedure was not followed by plaintiffs. The court denied relief on the theory that equity would not intervene if other effectual remedies exist. This theory has received little support or discussion in American courts.

28. See, e.g., Hickman v. Kline, 279 P.2d 662, 669 (Nev. 1955) (dictum) ; Murray v. Kelly, LAB. REL. REP. (36 L.R.R.M. 2667) (N.Y. Sup. Ct. Aug. 26, 1955) ; Porth v. Local 201, United Brotherhood of Carpenters, AFL, 171 Kan. 177, 231 P.2d 252 (1931); authorities cited in note 27 sttpra.

29. "The notion that members ... must await review of the legality of their ouster at a convention to be held almost two years thereafter ... simply shocks our sense of justice and we have no hesitancy in rejecting it." Naylor v. Harkins, 11 N.J. 435, 445, 94 A.2d 825, 830 (1953). See also Cameron v. Durkin, 321 Mass. 590, 74 N.E.2d 671 (1947); Summers, Legal Limitations on Union Discipline, 64 HARv. L. Rev. 1049, 1086-87 (1951). But cf. Porth v. Local 201, United Brotherhood of Carpenters, AFL, stpra note 28 (semble). 
nonmembers suing for benefits, ${ }^{30}$ membership ${ }^{31}$ or reinstatement ${ }^{32}$ must exhaust association remedies. Furthermore, the modern rule is that available remedies must be exhausted even if they are only permissive, and not required by the association's constitution or bylaws. ${ }^{33}$

Nevertheless, courts applying the exhaustion rule believe they are applying a contractual condition; ${ }^{34}$ when they depart from the rule they believe that they are creating exceptions to a mechanical doctrine. ${ }^{35}$ The result is an appearance of certainty which is often disrupted by an unexpected and inexplicable departure from the rule. ${ }^{30}$ For the courts' belief that exhaustion is a contractual condition has led to mechanical application of the rule in instances where its application was unjust, ${ }^{37}$ and to exceptions from the rule which, indiscriminately applied, threaten to swallow it whole. ${ }^{38}$ Furthermore, the contract rationale has not led to valid standards by which to decide in what instances, and to what extent, exceptions should be permitted. ${ }^{39}$ Some exceptions follow logically from the contract rationale without any further justification. ${ }^{40}$ Other exceptions are created without any rationale, or on a justifica-

30. King v. Wynema Council, Daughters of Pocahontas, 25 Del. (2 Boyce) 255, 78 Atl. 845 (1911). Some courts apply the exhaustion rule, but construe constitutional provisions strictly. Grubbs v. Comanche Tribe, 16 Ga. App. 11, 84 S.E. 494 (1915) (bylaws must have mandatory exhaustion requirement). See 2 BAcon, op. cit. supra note 9 , at 1547 .

31. Davis v. Brotherhood Ry. Carmen, AFL, 272 S.W.2d 147 (Tex. Civ. App. 1954).

32. Porth v. Local 201, United Brotherhood of Carpenters, AFL, 171 Kan. 177, 231 P.2d 252 (1951) ; Knauss v. Seventh-Day Adventist Ass'n, 117 Colo. 540, 190 P.2d 590 (1948) ; Grand Lodge v. Taylor, 79 Fla. 441, 84 So. 609 (1920) (beneficial saciety).

33. See notes $62-65$ infra and accompanying text.

34. Of twenty-five recent cases collected at random which stated a theory for imposing the exhaustion requirement, twenty-three relied on contract doctrine. The rationale is firm$1 \mathrm{y}$ entrenched and accepted in the law of associations. See Summers, Legal Limitations on Union Discipline, 64 HaRv. L. REv, 1049, 1054 (1951) ; Comment, 22 U. CHI. L. Rev. 694, 698 (1955) ; 7 C.J.S., Associations $\$ 11$ (b) (Supp. 1955). See note 19 supra.

35. See Naylor v. Harkins, 11 N.J. 435, 444, 94 A.2d 825, 829 (1953) ; Wilson v. Miller, 194 Tenn. 390, 250 S.W.2d 575 (1952) ; Pearson v. Anderburg, 28 Utah 495, 80 Pac. 307 (1905).

36. Compare, e.g., Kelman v. Kaplan, 91 N.Y.S.2d 165 (Sup. Ct. 1949) (plaintiff, attempting to place his name on union ballot for election scheduled for June, was denied relief because he had not appealed to the general board, which would not have taken action until July), with State ex rel. Weingart v. Board of Officers of G. U. Gesellschaft, 144 Wis. 516, 129 N.W. 630 (1911) (plaintiff's writ for reinstatement in elected office of beneficial association granted because remaining appeal could not be decided before term of office expired).

37. "The fact that hardship may be suffered during the pendency of the period when such proceedings are being taken ... does not obviate the necessity of their being taken..." Greenwood v. Building Trades Council, AFL, 71 Cal. App. 159, 172, 233 Pac. 823, 826 (1925). See also Kelman v. Kaplan, supra note 36.

38. See Waldman v. Ladisky, 101 N.Y.S.2d 87 (Sup. Ct. 1950); Vorenberg, stpra note 18, at 493. For detailed discussion see notes 66-77 infra and accompanying text.

39. See note 36 supra; notes $62-65$ infra and accompanying text; Vorenberg, supra note 18 , at 489.

40. The justification for allowing a plaintiff to short-circuit the appeals system if a remedy is "permissive" is based solely on a theory of contract. See notes $62-64$ infra and accompanying text. 
tion framed in contract language which is clearly an afterthought. ${ }^{41}$ And the wide range of unpredictably applied exceptions threatens to subvert the rule's effectiveness.

Yet the exhaustion rule could be applied to serve valid policy goals. In association disputes, there are three sets of interests involved: the interests of the association as such; the interests of the members of the association; and the interests of the courts. The exhaustion rule should be flexibly used to accommodate each of these often-competing interests. For there is also a fundamental public interest in promoting well-managed, autonomous associations which are able to perform their societal functions effectively, and still provide internally for the fair treatment of individual members who must be disciplined. ${ }^{42}$

The exhaustion rule is beneficial to the courts. Today there is a marked trend away from courtroom adjudication of disputes: administrative tribunals thrive; arbitration agreements cover ever-widening areas of dispute; prelitigation settlements are increasingly used and judicially favored.43 And yet dockets remain overcrowded. ${ }^{44}$ The exhaustion rule reduces litigation by forcing disputes through a private system, where they may be settled before reaching the courts. ${ }^{45}$ Moreover, the litigation that does come to the courts will be

41. The "void judgment" exception, discussed in text at notes $66-72$ infra, has no contractual justification, especially where the plaintiff's irregular treatment may be corrected within the association. Yet the courts explain it in contract language. See, e.g., Rueb v. Rehder, 24 N.M. 534, 174 Pac. 992 (1918). See also the leading case of White v. Kuzych, [1951] A.C. 585, 601 (P.C.) (affirming judgment of Court of Appeal for British Columbia), where the Privy Council plainly used the contract rationale as an afterthought to add weight to a conclusion it had already reached.

42. Chafee, The Internal Affairs of Associations Not for Profit, $43 \mathrm{HARv}$. L. Rev. 993, 1020-27 (1930), suggests that there are four considerations in association matters which must be balanced by the courts :

1) the public interest in promoting well-managed autonomous associations-the "living tree" policy;

2) the courts' interest in avoiding a morass of ritual and dogma-the "dismal swamp" policy;

3) the courts' interest in avoiding non-judicial, far-reaching issues-the "hotpotato" policy; and

4) the public interest in safeguarding members' rights in instances when menbership has become an economic necessity-the "stranglehold" policy.

43. See, e.g., Davis, Adamnistrative Law $\$ 2$ (1951) ; Sturges, Cases On Arbitratron Law preface (1953) ; 3 Moore, Federal Practice f 16.17 (2d ed. Supp. 1955) (Fed. R. Crv. P. 16 as settlement device).

The General Motors Corporation has established an administrative board of review to whom dealers may appeal when they feel a contract has been wrongfully canceled. BERLE, The 20th Century Capitalist Revolution 80 (1954).

4. See Evans, Calendar Congestion, 26 N.Y.S.B. BuLl. 368 (1954); Symposium, Congestion of the Docket, 28 CoNn. B.J. 369 (1954) ; Note, 54 Colun. L. REv. 110 (1954).

45. It is clear that some courts view encouragement of private settlement as one of the purposes served by the exhaustion rule. See Waldman v. Ladisky, 101 N.Y.S.2d 87, 91 (Sup. Ct. 1950) (" $[\mathrm{It}]$. . . keeps out of our courts inter-organizational disputes, which, 
increasingly structured, the issues increasingly narrowed, as the case progresses through the association's appellate hierarchy. ${ }^{40}$ Furthermore, the exhaustion rule may eliminate a needless waste of judicial time and duplication of litigation. For the aggrieved member who has short-circuited the association system, if he is denied judicial relief on the merits of his grievance, may still return to the association to continue litigation-and he may obtain a favorable verdict from higher authorities within the association. ${ }^{\mathbf{4 7}}$

The exhaustion rule is beneficial to the association. It permits those officials in positions of higher authority to implement uniform application of the association's policies throughout the organization, to maintain a check on the officials at inferior levels of the association hierarchy and to correct their errors. ${ }^{48}$ It permits the association to prevent its "dirty linen" from being "washed" in public by encouraging intra-association resolution of intra-association problems and disputes. Finally, it saves the association from the unnecessary expense of litigation that could have been avoided by an intra-association decision. ${ }^{40}$

Finally, the exhaustion rule is beneficial to the vast majority of association members. Few members appeal their disputes beyond the association level. . $^{\text {to }}$ The majority of members are benefited to the same extent as the association by requiring aggrieved members to seek their remedies within the association. They are further benefited to the extent that the exhaustion rule, properly applied, will tend to improve the machinery of the intra-organization appellate system. ${ }^{51}$

in all likelihood, could be adjusted without resort to the courts ...."); see Delaware Lodge v. Allmon, 1 Penne. 160, 165, 39 Atl. 1098, 1100 (Del. Super. Ct. 1897) (same).

It is difficult to determine whether the exhaustion rule actually causes a member to avoid bringing immature suits to court. Vorenberg, supra note 18, at 494 , states that abandonment of the exhaustion rule would not bring more cases to court. The nature of the rule is such, however, that its greatest impact might not be found by examining the relatively small number of cases, see note 14 supra, decided in the past 100 years, where plaintiffs were denied relief. Its influence as a deterrent, propounded and enforced by plaintiff's counsel rather than a judge, might be far greater than available secondary data suggest.

46. The problems are illustrated by Bonacum v. Murphy, 71 Neb. 487,104 N.W. 180 (1905), a suit by a bishop of the Roman Catholic Church to oust an excommunicated member from church property. In discussing the averments of the complaint, the court stated: "Whether or not these averments mean anything to a churchman, ... they are certainly without meaning to the Courts of the State." Id. at 490,104 N.W. at 181 . See also Chafee, supra note 42, at 1023, discussing the "dismal swamp" of dogma and ritual within many associations, and the utility of insulating the courts from the necessity of involvement therein.

47. E.g., Correia v. Supreme Lodge of Portuguese Fraternity, 218 Mass. 305, 105 N.E. 977 (1914) (member, expelled by executive board, reinstated by branch lodge after court had dismissed member's petition for mandamus compelling reinstatement).

48. See American Civil Liberties Union, Democracy in Trade Unions 73 (1943); cf. Chafee, supra note 42 , at 1027 .

49. See note 47 supra; cf. Oppenheim, Trade-Union Democracy, 1 Duke B.J. 234, 238-39 \& n.17 (1951).

50. Sce note 14 supra.

51. See note 48 supra. 
Of course, the majority's interests should not persuade the courts to ignore the rights and interests of the occasional member who does short-circuit the appellate system for cause. The rule should be flexibly applied, so that a member need not go through the motions of exhausting purported remedies that cannot in fact rectify the alleged wrong. Exceptions must be created. However, the exceptions should be created and limited in light of their function of protecting members' interests from the operation of a rule which ordinarily serves a useful purpose in American society.

\section{Exceptions to the Exhaustion Rule}

The most important and frequently used exceptions to the exhaustion rule are those permitted when adequate remedies do not in fact exist. This category of exceptions includes situations where there is no remedy at all; where apparent remedies will not rectify the wrong for which plaintiff is suing; where the association has prevented the member from receiving a fair hearing; and where protracted exhaustion of remedies will in itself aggravate the wrong.

Mechanical application of the exhaustion rule to these situations would doubtlessly lead to unjust treatment of many members, without implementing the policies the rule should serve. ${ }^{52}$ Nevertheless, these policies have invariably been ignored by courts creating exceptions to the rule.53 Thus members have been exempted from exhausting remedies that were in fact available to them. ${ }^{54}$ And the breadth of these exemptions threatens to undermine the entire foundation of the rule. ${ }^{55}$ Therefore, after current exceptions have been analyzed, an alternative classification of exceptions will be suggested which is aimed at requiring members to exhaust all real, but only real, remedies.

\section{Current Exceptions to the Exhaustion Rule}

\section{Illusory Remedies}

It is fundamental that a person will not be required to take intra-association appeals which cannot in fact yield remedies. ${ }^{56}$ Such appeals can be viewed as illusory conditions of the member's "contract" to exhaust his remedies within the association. ${ }^{57}$ The courts using the contract theory have rightly broadened

52. See note 37 supra.

53. Thus far, no judge appears to have made a thorough analysis of the rule in terms of the interests affected by it. For relatively sophisticated discussions, see Waldman v. Ladisky, 101 N.Y.S.2d 87 (Sup. Ct. 1950) ; Local 104, Int'1 Brotherhood of Boilermakers v. International Brotherhood of Boilermakers, 33 Wash. 2d 1, 203 P.2d 1019 (1949).

54. See, $c . g$., notes 66-75 infra and accompanying text, for discussion of the "improper jurisdiction" exception. See also note 61 infra.

55. See notes 73-75 infra and accompanying text; Vorenberg, Exhaustion of Intraunion Renedies, 2 LAB. L.J. 487, 493 (1951).

56. See Wilson v. Miller, 194 Tenn. 390, 250 S.W.2d 575 (1952) ; Born v. Cease, 101 F. Supp. 473, 475 (D. Alaska 1951) (dictum).

57. See cases cited notes 58-65 infra; Vorenberg, supra note 55, at 489. 
this exception to include remedies that exist in theory only. They have wrongly broadened it to include some remedies that in fact are available to the member.

It is generally held that a member need not exhaust "remedies" that are not provided for in the association's administrative machinery. 58 Nor need he exhaust remedies provided only after his suit has been instituted.50 Furthermore, he is not required to appear before tribunals that cannot offer full relief for his grievances. Thus, if appellate boards have no power to force a lower tribunal to correct its action or to undo the particular wrong a member is seeking to remedy, the member need not appeal from the lower tribunal's decision. ${ }^{60}$

Although the courts should require the member to exhaust all bona fide remedies within the organization, some do not. ${ }^{61}$ Thus, some courts refuse to require exhaustion of intra-association appeals which are permissive rather than mandatory. ${ }^{62}$ The rationale is strictly doctrinal, based upon the assumption that if the appeal is "merely permissive," it is not a contractual condition precedent to the member's suit. ${ }^{63}$ The better rule, now followed in many courts,

58. Hooper v. Stone, 54 Cal. App. 668, 202 Pac. 483 (1921) (no tribunal exists) ; Crowden v. Dieu Nous Protege Benevolent Mut. Aid Ass'n, 146 So. 710 (La. App. 1933) (constitution describes no remedies) ; Evans v. Brown, 134 Md. 519, 107 Atl. 535 (1919) (same); Marchitto v. Central R.R., 9 N.J. 456, 88 A.2d 851 (1952) (constitution construed so as not to provide remedy).

59. Armstrong v. Duffy, 90 Ohio App. 233, 103 N.E.2d 760 (1951).

60. Brown v. Harris County Medical Soc'y, 194 S.W. 1179 (Tex. Civ. App. 1917) (plaintiff, expelled member of defendant local medical society, excused from appealing to state medical association because that body had no power to cause plaintiff's reinstatement) ; Preveden v. Croatian Fraternal Union, 120 F. Supp. 33 (W.D. Pa. 1954) (high trial board need not be appealed to, since it could not assess money damages against the association); Browne v. Hibbets, 290 N.Y. 459,49 N.E.2d 713 (1943) (tribunal had no power to remove the "black mark" of a fine).

61. See, e.g., Kaminski v. Hoynak, 373 Pa. 194, 95 A.2d 548 (1953); Coleman v. O'Leary, 58 N.Y.S.2d 812 (Sup. Ct. 1945). See also Wilson v. Miller, 194 Tenn. 390, 250 S.W.2d 575 (1952) (plaintiff could have appealed to the general executive board, and then to the general convention, but demurrer to the complaint was overruled on grounds of "futility") ; Harris v. National Union of Marine Cooks, 98 Cal. App. 2d 733, 221 P.2d 136 (1950) (semble) (no need to exhaust remedy which appeared in penalty rather than remedies section of the constitution).

62. See notes 63-64 infra. See also Grubbs v. Comanche Tribe, 16 Ga. App. 11, 84 S.E. 494 (1915) (must have mandatory exhaustion requirement in bylaws to force beneficiary to appeal for death benefits within the association) ; Mullen v. Court Queen City, Order of Foresters, 70 N.H. 327, 47 At1. 257 (1900) (same, but there must be appeal on sickness benefits due the deceased); see 2 Bacon, op. cit. supra note $9, \S 624$.

63. The permissive-mandatory distinction was originally made by judges faced with insurance claims against beneficial societies. They apparently felt constrained to read bylaws narrowly when such claims were involved, and to require exhaustion only when the bylaws were cast in imperatives. Voluntary Relief Dep't v. Spencer, 17 Ind. App. 123, 46 N.E. 477 (1897) (provision making all controversies subject to the right of appeal to the advisory committee construed as permissive and not obligatory); Bauer v. Samson Lodge, Knights of Pythias, 102 Ind. 262, 1 N.E. 571 (1885) (one who asserts a claim for money due upon a contract occupies an essentially different position from one who presents a question of discipline) ; Supreme Lodge of Order of Select Friends v. Dey, 58 Kan. 283, 49 
is to require the member to take any appeal that is in fact available, whether or not he has a "contractual duty" to do so. ${ }^{64}$ However, the courts should not insist that the appeal be formally provided for within the constitution or bylaws; it should be sufficient that the organization, as a matter of custom and practice, has always entertained such appeals. ${ }^{65}$

\section{Bias, Lack of Notice, Lack of Hearing}

The courts often permit members to short-circuit the association's appellate system if the organization's officials have, by their own actions, precluded the member from having a fair and effective trial or appeal. ${ }^{66}$ This exception extends to instances in which the member was not given due notice, ${ }^{67}$ right of hearing ${ }^{68}$ or review, ${ }^{69}$ and to instances in which the association's officials were

Pac. 74 (1897) (permissive appeal is for the member's benefit, not the association's). See note 62 supra.

64. Robinson v. Irish-American Benevolent Soc'y, 67 Cal. 135, 7 Pac. 435 (1885) ; King v. Wynema Council, Daughters of Pocahontas, 25 Del. (2 Boyce) 255, 78 Atl. 845 (1911); Powtney v. Bachman, 31 Hun 49 (N.Y. Sup. Ct. 1883). In recent cases plaintiff has been required to exhaust his remedies even though the language was clearly permissive; the point was not even raised. Rule v. Brotherhood's Relief and Compensation Fund, 251 S.W.2d 309 (Tenn. App. 1952) ; Nadeau v. St. Albans Aerie, 112 Vt. 397, 26 A.2d 93 (1942).

The permissive-mandatory exception is not usually raised in suits that do not involve benefit claims. North Dakota v. North Central Ass'n, 99 F.2d 697 (7th Cir. 1938) ; Durkin v. Murray, 90 F. Supp. 367 (D.D.C. 1950) ; Gardner v. East Rock Lodge, 96 Conn. 198, 113 Atl. 308 (1921) (dictum). But see Lo Bianco v. Cushing, 117 N.J. Eq. 593, 177 At1. 102 (Ch. 1935); Way v. Patton, 195 Ore. 36, 241 P.2d 895 (1952) (dictum).

65. The law seems to be that a person need exhaust only those remedies actually described in the formal constitution or bylaws. See note 58 supra. But in Olear v. Haniak, 235 Mo. App. 249, 131 S.W.2d 375 (1939), faced with the Roman Catholic appeals system, the court dismissed plaintiff's suit for failure to exhaust remedies on the basis of verbal testimony describing the system. See also St. Nicholas Ruthenian Greek Catholic Church v. Bilanski, 19 Del. Ch. 49,162 Atl. 60 (Ch. 1932) (same).

66. Wilson v. Miller, 194 Tenn. 396, 250 S.W.2d 575 (1952) (plaintiff may resort to the courts where he does not have an opportunity to present his claim and have a fair determination of it, due to bad faith, fraud, malice or arbitrary or oppressive action by the association) ; Schou v. Sotoyome Tribe, 140 Cal. 254, 73 Pac. 996 (1903) (before an association can invoke the exhaustion doctrine, it must show that it has itself observed the appeal regulations) ; Mfyers v. Jenkins, 63 Ohio St. 101, 119-22, 57 N.E. 1089, 1093-94 (1900) (dictum) (exhaustion will not be required where it is the association's fault that it has not been accomplished).

67. Swital v. Real Estate Comm'r, 116 Ca1. App. 2d 677, 254 P.2d 587 (1953) ; Slater v. Supreme Lodge, 76 Mo. App. 387 (1898) ; Langnecker v. Trustees of Grand Lodge, 111 Wis. 279, 87 N.W. 293 (1901) ; Thorn v. Foy, 328 Mass. 337, 103 N.E.2d 416 (1952) (scmble) (exception applied, but held no excuse for non-exhaustion because additional appeals were available).

68. Yockel v. German-American Bund, 20 N.Y.S.2d 774 (Sup. Ct. 1940) (summary expulsion); Kempton Lodge v. Mozingo, 180 Ind. 566, 103 N.E. 411 (1913) (refusal to grant a trial) ; Malmsted v. Minneapolis Aerie, 111 Minn. 119, 126 N.W. 486 (1910) (expulsion without trial).

69. Wilson v. Miller, 194 Tenn. 390, 250 S.W.2d 575 (1952) (appeal to general presi- 
biased or had prejudged the member's case before they heard it. ${ }^{70}$ It cannot be denied that a hearing before these officials is illusory. However, this exception is in practice the most dangerous of all to the rule's integrity. For the courts have widened the exception to permit the member to by-pass the entire appellate system once he has shown that there was bias or a procedural defect at one level along the appellate ladder. Bias, prejudgment or noncompliance with any bylaw have been held to constitute breach, by the association, of the contract compelling the member to exhaust internal remedies. ${ }^{71}$ And, by analogy to rules of judicial procedure, some courts have held that a board which failed to grant due notice or hearing never had proper jurisdiction over the member; they have concluded that immediate recourse to the courts was available, either because the association's appellate boards had no jurisdiction to review a judgment void $a b$ initio, or that the judgment, being void for want of jurisdiction, was immediately subject to collateral attack in the courts. ${ }^{72}$

dent, who refused to take action) ; Browne v. Hibbets, 290 N.Y. 459, 49 N.E.2d 713 (1943) (two appeals to the council unanswered).

70. Generally, the tribunal accused of prejudging or bias contains more than one person. Although the courts accept bias as an exception, they differ on the degree of taint necessary to render an appeal to the tribunal "futile." Bias was found in Blenko v. Schmeltz, $362 \mathrm{~Pa}$. 365, 67 A.2d 99 (1949) (board had adopted resolution that plaintiff was guilty before trying him, and one member of the board had himself brought the charges); Coleman v. O'Leary, 58 N.Y.S.2d 812 (Sup. Ct. 1945) (one man acting as witness, prosecutor and judge). But in the following cases, courts considered the evidence insufficient to constitute grounds for making an exception to the exhaustion rule. Correia v. Supreme Lodge of Portuguese Fraternity, 218 Mass. 305, 105 N.E. 977 (1914) (minority of tribunal prejudiced); Hall v. Morrin, 293 S.W. 435 (Mo. App. 1927) (personnel of appellate tribunal similar to that of accusers); Way v. Patton, 195 Ore. 36, 241 P.2d 895 (1952) (three out of thirteen members had prejudged) ; Barthell v. Zachman, 162 Tenn. 336, 36 S.W.2d 886 (1931) (trial commission appointed by alleged wrongdoer).

71. New York carries the "void judgment" exception to the furthest extreme. In Yockel v. German-American Bund, 20 N.Y.S.2d 774 (Sup. Ct. 1940), the plaintiff applied for reinstatement after being summarily expelled from the Bund, contrary to its rules. The court said that "where irregularities in procedure and non-compliance with by-laws and the constitution are alleged, immediate recourse may be had to the courts. ..." Id. at 778 (dictum). If the dictum in Yockel were the rule, exhaustion of remedies would be excused by an allegation of irregularities refutable only after a hearing on the merits. Generally, however, the courts require a showing of irregular proceedings before allowing the exception. This rule is firmly entrenched in most important jurisdictions. E.g., Swital v. Real Estate Comm'r, 116 Cal. App. 2d 677, 254 P.2d 587 (1953) ; Coleman v. O'Leary, 58 N.Y.S.2d 812 (Sup. Ct. 1945) ; Kaminski v. Hoynak, 373 Pa. 194, 95 A.2d 548 (1953).

72. The "void judgment" exception probably developed as an attempt to avoid the exhaustion rule where its use would create hardship. Since, however, hardship has not been required in order to invoke the exception, the effect is completely to avoid the exhaustion rule. For any grounds which could lead to victory on the merits would also be sufficient to persuade the court to grant the exception. See Summers, Legal Limitations on Union Discipline, 64 HaRv. L. REv. 1049, 1091-92 (1951).

The exception is usually supported by one of two theories:

(1) Collateral Attack of Null and Void Judgment

"If the action of the lodge be a usurpation, ... . it may be likened to a judgment rendered by a court which has no jurisdiction of the subject-matter or of the person .... It 
It is inconsistent with the policy purposes served by the exhaustion rule to permit a member to go directly to the courts because of a procedural defect or showing of bias at a lower level of the association's appellate system. Admittedly, a biased judgment or an ex parte hearing should not be permitted to stand. Nor should a member be required to appeal to a board that has prejudged his case, or failed to grant him adequate notice or hearings. If, however, there is an unbiased tribunal higher in the organization's hierarchy that is able to reverse the action of the lower board, the policies behind the exhaustion rule demànd that the member should appeal to the higher tribunal. ${ }^{73}$ Otherwise, the exception will swallow the rule. For a member will seldom seek access to the courts unless the organization has at some level proceeded irregularly or arbitrarily. ${ }^{74}$ And in order to determine whether there was a procedural defect, the court would be forced to delve into the organizational

is void in all courts and places, and the duty of an expelled member to exhaust ... all the remedies within the organization, arises only where the association is acting strictly within the scope of its powers." Malmsted v. Minneapolis Aerie, 111 Minn. 119, 122, 126 N.W. 486, 487 (1910) ; Swital v. Real Estate Comm'r, 116 Cal. App. 2d 677, 254 P.2d 587 (1953); Kaminski v. Hoynak, $373 \mathrm{~Pa} .194,95$ A.2d 548 (1953).

(2) Mutuality of Obligations

The contractual duty to exhaust remedies need not be fulfilled if the association, by improper treatment, has breached its contract with the member. Rueb v. Rehder, 24 N.M. 534, 174 Pac. 992 (1918) ; Slater v. Supreme Lodge, 76 Mo. App. 387 (1898); Schou v. Sotoyome Tribe, 140 Cal. 254, 73 Pac. 996 (1903) (dictum).

The trend today seems to be uncritical acceptance of the exception, and application of it unaccompanied by rationale. See, e.g., Harris v. National Union of Marine Cooks, 98 Cal. App. 2d 733, 221 P.2d 136 (1950); Weber v. Marine Cooks' \& Stewards' Ass'n, 93 Cal. App. 2d 327, 208 P.2d 1009 (1949); Coleman v. O'Leary, 58 N.Y.S.2d 812 (Sup. Ct. 1945) ; Summers, supra, at 1091-92; Vorenberg, supra note 55, at 489; Comment, 22 U. CHI. L. Rev. 694, 698-99 (1955).

73. Parallel to the line of "void judgment" cases is an equally impressive, although less-cited, series of cases which hold that a defect along the line of appeal does not excuse compliance with the exhaustion requirement. In Thorn v. Foy, 328 Mass. 337, 103 N.E.2d 416 (1952), the plaintiff was expelled from the union. Rather than appeal to the next level, he alleged lack of notice and faulty trial, and attempted to obtain immediate judicial relief. It was held that the organization's failure to comply with its bylaws was no excuse for failure to exhaust remedies, since the defect could have been the subject of an appeal under the constitution. See also Zeidler v. Knights of Columbus, $172 \mathrm{Kan} .557,241$ P.2d 761 (1952) (biased tribunal) ; Nadeau v. St. Albans Aerie, 112 Vt. 397, 26 A.2d 93 (1942) (president's refusal to process claim in improper form); Barthell v. Zachman, 162 Tenn. 336, 36 S.W.2d $\$ 86$ (1931) (prejudging); Braden v. Lewis, 148 La. 920, 88 So. 117 (1921) (improper trial, arbitrary and ultra vires actions); Grand Lodge, Knights of Pythias v. Taylor, 79 Fla. 441, 84 So. 609 (1920) (expulsion without trial); Jeane v. Grand Lodge, Ancient Order United Workmen, 86 Maine 434, 30 Atl. 70 (1894) (irregular proceedings); Zeliff v. Grand Lodge of Knights of Pythias, 53 N.J.L. 536, 22 Atl. 63 (Sup. Ct. 1891) (irregular and illegal expulsion) ; Screwmen's Benevolent Ass'n v. Benson, $76 \mathrm{Tex} .552$, 13 S.W. 379 (1890) (expulsion allegedly contrary to association's constitution and the law).

74. Waldman v. Ladisky, 101 N.Y.S.2d 87, 91 (Sup. Ct. 1950). See also note 38 supra; Summers, Legal Limitations on Union Discipline, 64 HARv. L. Rev. 1049, 1091-92 (1951). 
maze of the association; in order to determine whether there had been a prejudgment, the court would often have to adjudicate the merits of the controversy. ${ }^{75}$

It is fundamental that the higher authorities of the association should be charged with primary responsibility for reviewing the decisions of lower tribunals within the hierarchy, and reversing their decisions when they fail to correspond with what the higher tribunal determines to be the proper policy or procedure. ${ }^{76}$ Moreover, it is not at all unfair to the member to require him to take his appeal to the association's highest tribunal so long as he will receive a fair hearing before them, and so long as they are able to remedy the wrong which he believes he has suffered at the association's hands. ${ }^{77}$

\section{Unjust Burden}

The courts also permit members to go directly to court, by-passing appeals still available within the association, if it would be unreasonably burdensome to the member to take the appeal. ${ }^{8}$ Thus, if the next appeal is to a national convention which will not convene for several years or which is financially or geographically inaccessible to the member, he is generally not required to undertake the burden of appealing to the convention. ${ }^{79}$

This exception seems perfectly sound. But courts should not set arbitrary limits beyond which delayed appeals are considered futile. ${ }^{80}$ With this qualification, the exception points toward the only proper exception to the exhaustion rule: a flexible determination whether the lapse of time, in conjunction with the nature of the injury suffered by the member in the interim, warrants immediate admission to the courts.

75. This was the result in cases cited in notes 71,72 supra.

76. See notes 56-70 supra and accompanying text.

77. In Zeidler v. Knights of Columbus, 172 Kan. 557, 241 P.2d 761 (1952), the plaintiff had been tried, but had not been deprived of any of the privileges of the beneficial society. He alleged that his trial had been removed to the board of directors, which had accused him of the offense, and that a fair trial would therefore be impossible. In sustaining the society's demurrer, the court held that thus far a fair hearing had not been denied, and it would not assume jurisdiction of the dispute until the remedies were actually exhausted.

78. 2 BAcon, op. cit. supra note 9, \$ 625; Summers, Legal Limitations on Union Discipline, 64 HARv. L. Rev. 1049, 1086-88 (1951) ; Vorenberg, supra note 55, at 489-90. Sce dictum in Greenwood v. Building Trades Council of Sacramento, AFL, 71 Cal. App. 159, 168, 233 Pac. 823, 826 (1925).

79. E.g., Local 4, Nat'1 Organization Masters v. Brown, 258 Ala. 18, 61 So. $2 \mathrm{~d} 93$ (1952) (great expense, inconvenience and loss of time taking appeal to executive committee and convention in Washington, more than a year later) ; Local 104, Int'1 Brotherhood of Boilermakers v. International Brotherhood of Boilermakers, 33 Wash. 2d 1, 203 P.2d 1019 (1949) (no certain meeting date for convention); Beedie v. International Brotherhood of Electrical Workers, 25 N.J. Super. 269, 96 A.2d 89 (App. Div. 1953) (convention at distant time and place).

80. Cf. 2 Bacon, op. cit. supra note 9, $\$ 625$; Summers, Legal Limitations on Union Discipline, 64 Harv. L. Rev. 1049, 1087-88 (1951). 


\section{A Single-Exception Proposal}

Members of private associations should be required to exhaust every effective appeal available within the association unless they affirmatively prove that requiring continued intra-association appeals would subject them to injury that is, in a practical sense, irreparable. If a member is being subjected to severe, continuing injury due to a penalty imposed by the association's lower tribunals, and if there will be substantial delay before his intra-association appeal can be heard, that delay will in itself aggravate the injury and make it "irreparable"; by definition, no future remedy can afford full relief. Thus a person expelled from a union and suing for readmittance should not be required to litigate through the hierarchy of appellate boards within the union if, during the interim, he is barred from work in union shops. The exhaustion requirement should be suspended unless the imposition of penalty-in this instance, denial of membership rights-is stayed. ${ }^{81}$

The courts can prevent irreparable injury to plaintiffs without destroying the vitality of the exhaustion rule. Difficulties will be avoided, of course, when the association voluntarily stays imposition of penalty; many associations are required to do so by their constitutions. ${ }^{82}$ But even assuming that the association has failed to stay penalties, ${ }^{83}$ and severe injury is threatened, courts need not automatically suspend operation of the exhaustion rule in order to protect the rights of the aggrieved member. Instead, they can enforce the rule but grant the member a temporary injunction staying imposition of penalty while he is taking intra-association appeals. ${ }^{84}$

81. It is recognized that courts will tend to impose the exhaustion requirement less strictly where plaintiff is thereby subjected to serious injury. See Vorenberg, supra note 55 , at 490 . A number of cases seem to have turned upon the likelihood of injury to plaintiff due to imposition of the exhaustion rule. See, c.g., Naylor v. Harkins, 11 N.J. 435, 94 A.2d $\$ 25$ (1953) (exhaustion excused; plaintiff's opportunity to work in union shop was jeopardized); Browne v. Hibbets, 290 N.Y. 459, 49 N.E.2d 713 (1943) (loss of employment) ; Seligman v. Toledo Moving Pictures Operators Union, 88 Ohio App. 137, 98 N.E. 2d 54 (1947) (same). See also Way v. Patton, 195 Ore. 36, 241 P.2d 895 (1952) (court, denying writ, noted that case did not involve loss of employment) ; Camp No. 6, Patriotic Order Sons of America v. Arrington, 107 Md. 319, 68 Atl. 548 (1908) (court, denying writ, noted that plaintiff had not shown imminent injury). See notes 98-102 infra and accompanying text. Hardship, however, has not been a generally accepted criterion for applicability of the rule. See notes 37 supra, 83 infra.

82. See Cunningham v. Milk Drivers and Dairy Employees, 144 N.Y.S.2d 790 (Sup. Ct. 1955); Minch v. Lacal 370, Int'l Union of Operating Engineers, 44 Wash. 2d 15, 265 P.2d 286 (1953) ; Otis \& Co. v. National Ass'n of Securities Dealers, 84 F. Supp. 395 (D.N.C. 1949) ; Browne v. Hibbets, 290 N.Y. 459 , 49 N.E.2d 713 (1943).

83. It has been held that a union need not stay the penalty during appeal. Leahigh $\mathrm{v}$. Beyer, 116 N.E.2d 458 (Ohio C.P. 1953).

84. The injunction should be so worded that the association has the option of staying the penalty or waiving the exhaustion rule. For example: "The association is enjoined from imposing discipline which might be irreparably injurious to the plaintiff (as specified); prozided that such discipline may be imposed after the association's highest tribunal has frassed on the case or waived its privilege to do so; and provided further that the associa- 
A flexible use of the temporary injunction would protect both court and member. The injunction would protect plaintiff fully; it would prevent the association from penalizing him until a final disposition of his dispute is rendered by the association's highest authorities. It would also prevent the court from becoming prematurely embroiled in disputes. For, although the injunction must be based upon proof of severe interim injury, ${ }^{85}$ and a colorable claim for relief, it should not be contingent upon a showing that plaintiff would probably win on the merits if he did not have to exhaust his remedies. Such a requirement would defeat the purpose of the exhaustion rule, which is to defer judicial consideration of a controversy until all intra-association appeals have been taken. ${ }^{86}$

Furthermore, the injunction need not prejudice the interests of the association. In order to prevent dilatory tactics by plaintiff, the injunction could be expressly conditioned upon prompt exhaustion of all available remedies. ${ }^{87}$ Moreover, the association would not be compelled to allow the member to litigate within the association. It would, of course, be compelled to treat the member fairly if it wished him to keep his dispute within association channels. But if the association officials preferred to impose penalties upon him at once, they could waive the necessity of further appeals. Alternatively, they could telescope intermediate appellate stages and accelerate hearings so that the case could be heard at once by the highest-level authorities. In either instance penalties could be imposed without substantial delay. However, the suit would then be "ripe" for judicial review. ${ }^{88}$

It seems apparent that members of private associations should always be re-

tion need refrain only so long as the member processes his appeal in good faith, and with reasonable speed."

85. Such injury should be severe, but the test should not be so restrictive as the traditional equity definition of irreparable injury, which is limited to those injuries which are incapable of being completely remedied at law. See 4 Pomerox, EQUity JuRISPRUdence 936 (5th ed. 1941). If the discipline will impose severe and extraordinary financial burdens on the member, a temporary injunction should issue. Application of the exception would necessarily be left to the equitable discretion of the court. This discretion should be attuned however, to the valid policy purposes served by employing the exhaustion rule. See notes $42-51$ supra and accompanying text. For an illustrative listing of cases which should merit such relief, see note 81 supra.

86. See text at note 93 infra.

87. See note 84 supra for proposed wording of the injunction.

88. An association can always so conduct itself that there will be no adequate remedies for the plaintiff to exhaust. See note 66 supra and accompanying text. Furthermore, the association has the burden of pleading failure to exhaust, and may refuse to raise it as a defense. See note 96 infra and accompanying text. Consequently, the association can and should be able to waive the exhaustion requirement when it no longer cares to entertain the member's appeal. Such waiver was found in Seligman v. Toledo Moving Pictures Operators Union, 88 Ohio App. 137, 98 N.E.2d 54 (1947). But see Barthell v. Zachman, 162 Tenn. 336, 36 S.W.2d 886 (1931) (exhaustion of remedies a jurisdictional prerequisite which cannot be fulfilled by waiver). 
quired to exhaust all effective opportunities to settle their disputes with the association. If no further remedy is in fact available, or if a fair hearing cannot be obtained, the requirement is satisfied. But if there is an effective opportunity to correct these defects and obtain relief at a higher appellate level, where a fair hearing can be obtained, the member should never be permitted to by-pass appeal because of defective proceedings at an inferior level. When it is proved that the member will be subjected to irreparable, continuing injury if he remains under penalty while waiting to perfect an appeal, the courts should stay imposition of the penalty by use of an injunction pendente lite. But they should never permit the member to avoid an appeal when the association makes it reasonably available to him.

\section{Procedural Disposition of the Exhaustion Rule: Burden of Proof, Burden of Pleading, Questions for JuRY}

Under the contract rationale, exhaustion of intra-association remedies is a condition precedent to a member's suit against an association. ${ }^{89}$ Accordingly, most courts have held that plaintiff must allege and prove performance of the condition..$^{90}$ If the allegation is denied by defendant, the issue is generally treated as a question of fact to be decided by the jury.91 Moreover, the question is seldom decided by court or jury until evidence on all other issues, including the merits of the dispute, has been presented. ${ }^{92}$

The question of exhaustion, if it is put in issue, should be determined before submitting evidence on - and a fortiori before deciding the merits of any dispute. Until the exhaustion question is settled, no other aspect of the litigation should be heard. After evidence on the merits has been submitted, it is likely that the decision whether plaintiff has exhausted his remedies will be influenced by the relative merits of the dispute itself. And the purpose of the exhaustion rule is to avoid litigation of complex and immature-not unmeritorious-disputes. This purpose cannot be accomplished by a finding, after

89. See notes $27-28$ supra and accompanying text.

90. E.g., Zdero v. Briggs Mfg. Co., 338 Mich. 549, 61 N.W.2d 615 (1953) ; Nadeau v. St. Albans Aerie, 112 Vt. 397, 26 A.2d 93 (1942) ; Coffey v. Los Angeles Firemen's Relief Ass'n, 22 Cal. App. 2d 510, 71 P.2d 328 (1937) ; Horst v. Traudt, 43 Colo. 445, 96 Pac. 259 (1908); cf. Preveden v. Croatian Fraternal Union, 120 F. Supp. 33 (W.D. Pa. 1954); Crowden v. Dieu Nous Protege Benevolent Mut. Aid Ass'n, 146 So. 710 (La. App. 1933); Barthell v. Zachman, 162 Tenn. 336, 36 S.W.2d 886 (1931).

91. Born v. Cease, 101 F. Supp. 473 (D. Alaska 1951); Vycas v. St. George Guard Soc'y, 97 Conn. 509, 117 Atl. 692 (1922) ; Minch v. Local 370, Int'l Union of Operating Engineers, 44 Wash. 2d 15, 265 P.2d 286 (1953).

92. Usually the jury is charged to find for defendant if plaintiff failed to exhaust remedies. There is no way to insure that the jury has considered the exhaustion question, hecause it will usually return a general verdict. See Vycas v. St. George Guard Society, 97 Conn. 509, 117 Atl. 692 (1922) ; McGuiness v. Court Elm City, Foresters of America, 78 Conn. 43, 60 Atl. 1023 (1905) ; Myers v. Jenkins, 63 Ohio St. 101, 57 N.E. 1089 (1900). 
the trial has been completed, that suit should not have been brought in the first place because plaintiff had failed to exhaust his remedies. ${ }^{93}$

Moreover, the issue whether plaintiff did exhaust remedies should be tried to the court without jury. For the exhaustion rule is not a simple condition precedent to a contract action; it is a rule of procedure which courts should use to determine whether a particular dispute is "ripe" for adjudication. There is no reason to submit this question, more than other questions of procedure, to a jury. ${ }^{94}$ The jury is likely to decide the question in terms of the substantive merits of the dispute. Indeed, there is especially strong reason for the court to determine this particular question of procedure, because the court itself has a direct interest in avoiding premature litigation. ${ }^{95}$

Finally, the association should have the burden of pleading and coming forward with evidence showing that plaintiff failed to exhaust his remedies. As a practical matter, the association's officials will have far greater knowledge of the remedies that were available to plaintiff and of the procedural requirements involved at each appellate step. ${ }^{96}$ However, once defendant has pleaded facts and introduced evidence (including affidavits) showing the existence of a remedy which plaintiff failed to exhaust, the burden should be on plaintiff to prove either that he did exhaust all remedies known and reasonably available to him, or that requiring exhaustion of remedies would subject him to continuing injury. In this way, each party would have the burden of coming forward with evidence more likely to be within its control.

\section{Scope of the Exhaustion Rule: Parties, Issues, Associations}

\section{Parties and Issues Subject to the Exhaustion Rule}

Under the contract rationale, only a member is required to exhaust intraorganizational remedies provided by an association. If a person is expelled from an association, and sues in damages for wrongful expulsion rather than reinstatement, courts often hold that the expulsion has terminated his contractual obligations and that he is no longer required to comply with the asso-

93. This purpose of the rule has not been appreciated by all courts. See Weinstock v. Ladisky, 197 Misc. 859, 872, 98 N.Y.S.2d 85, 98 (Sup. Ct. 1950) : "While . . plaintiffs have failed to exhaust their remedies ... and that would suffice to dispose of the motions presented, if the motions may be decided on the merits and the litigation thus brought to finality, then obviously it would be proper to make such a final determination." See also Jones v. Hansen, 220 La. 673, 57 So. $2 d 224$ (1952).

The merits of this line of argument are obvious but few. When and if plaintiff exhausts his remedies, the court could then review the record on the merits. The fact that a record has been compiled, however, does not mean that association officials should not have the opportunity to correct any abuses before the case is brought to court on its merits. See Brown v. Harris County Medical Soc'y, 194 S.W. 1179, 1181 (Tex. Civ. App. 1917).

94. See, generally, Clark, Code Pleading 520 (2d ed. 1947).

95. See notes $43-47$ supra and accompanying text.

96. The appeals system in many organizations is often obscure to all but a few members, particularly when the organization officials do not publish a description of the system. Cf. cases cited note 65 supra. 
ciation's rules. ${ }^{97} \mathrm{~A}$ similar rationale is sometimes applied when a nonmember sues for rights of membership or other benefits. ${ }^{98}$

The application of the exhaustion rule should turn upon the types of issues involved in a suit, and not the membership status of the party bringing the suit or the type of remedy he seeks. The rule is justified because it keeps certain types of issues out of court until the proper authorities within an organization have been given a chance to pass upon them. ${ }^{99}$ Thus even nonmembers should be required to exhaust remedies available to them within an association before they bring a suit involving the internal policies, functions or administration of an association. ${ }^{100}$ An expelled "member" suing for damages for wrongful expulsion should be required to exhaust intra-association remedies as if he were suing for readmittance. ${ }^{101}$ Conversely, members should not be required to exhaust remedies in suits that do not involve these issues. Thus, if an association member is injured in a fall on the association's negligently kept stairway, that member should be able to sue the association immediately in tort, without being required to exhaust his remedies. ${ }^{102}$ Such a suit would reach none of the secrets, policies or practices of the association.

\section{Types of Associations Subject to the Exhaustion Rule}

It is "black letter" law that a court will not entertain a member's suit against his association unless the member alleges injury to a "property"

97. E.g., Independent Order, Sons and Daughters of Jacob v. Wilkes, 98 Miss. 179, 53 So. 493 (1910) ; Slater v. Supreme Lodge, 76 Mo. App. 387 (1898); St. Louis \& S.W. Ry. v. Thompson, 102 Tex. 89, 113 S.W. 144 (1908). Summers, Legal Limitations on Union Discipline, 64 Harv. L. Rev. 1049, 1088 (1951), claims this exception is "uniformly held." But see cases cited in note 101 infra.

98. See notes 30-32 supra and accompanying text.

99. See notes 43-51 supra and accompanying text.

100. See cases cited note 101 infra. But see Preveden v. Croatian Fraternal Union, 120 F. Supp. 33 (W.D. Pa. 1954); Jones v. Hansen, 220 La. 673, 57 So. 2d 224 (1952). Both suits were brought against an association for a tort. In Preveden a member sued for defamation of character arising from derogatory articles published in the saciety's magazine. In Jones an expelled member sued for libel because the union published false charges and circulated a black list with his name on it. Both cases concerned disputes between member and organization over internal policy, and should have been subject to the exhaustion rule. This seems especially true in the Jones case, which turned entirely on the legality of Jones' expulsion. In Preveden, however, the court refused to apply the exhaustion rule because the tribunal supposedly had no authority to pay damages. And in Jones, the court simply decided the case on the merits without even considering the exhaustion defense.

101. Minch v. Lacal 370, Int'l Union of Operating Engineers, 44 Wash. 2d 15, 265 P.2d 286 (1953). But sec Malmsted v. Minneapolis Aerie, 111 Minn. 119, 122, 126 N.W. 486, 487 (1910).

102. See Fireman's Fund Indemnity Co. v. Longshore Beach and Country Club, 127 Conn. 493, 18 A.2d 347 (1941) (failing to mention exhaustion requirement); Briggs v. Minnesota Delta Upsilon Club, 212 Minn. 14, 2 N.W.2d 151 (1942) (same); Traub v. Progress Country Club, 256 App. Div. 249, 9 N.Y.S.2d 501 (1st Dep't 1939) (same). 
right. ${ }^{103}$ This is true even if the member has exhausted his remedies. As a practical matter, however, "property" has been defined in this context to mean the kind of interest about which the courts will entertain a suit; there is a "property" interest in virtually every association suit if the court wishes to acknowledge it. ${ }^{104}$ The courts have used the property rationale primarily as a tool by which to avoid disputes involving certain types of associations, mainly those of religious character. ${ }^{105}$

Modern courts tend to speak less about "property" rights, but achieve the same results by applying the exhaustion rule more stringently against members of social or religious associations than against members of associations of substantial economic significance. ${ }^{106}$ There has been a noticeable tendency to apply the exhaustion rule very loosely, and to subject it to sweeping exceptions, in cases involving associations of great economic consequence. This tendency has been so strong that many writers have concluded that, as it concerns those "public" associations, the rule is a sham. ${ }^{107}$

Nevertheless, the exhaustion rule should apply equally to members of all associations. There is such a wide difference between a church and a labor union that the validity of classifying both as "private, voluntary associations" might well be questioned. ${ }^{108}$ It is easy to understand why courts are anxious to avoid the "dismal swamp"109 of ritual and dogma of social and religious associations, and to encourage members to settle their disputes wholly within their own organizations. It is easy to understand, also, why courts are solicitous of the rights of members of unions, trade and professional associations: in terms of economic fact, membership in these organizations is not "voluntary" but necessary for survival. ${ }^{110}$ The policy reasons supporting the exhaustion rule apply, however, to both types of associations. The broader economic impact

103. 4 Am. Jur., Associations and Clubs $\$ 18$ (1936); Chafee, The Internal Affairs of Associations Not for Profit, 43 HARv. L. Rev. 993, 999 (1930) ; Summers, Legal Limitations on Union Discipline, 64 id. 1049, 1051 (1951).

104. See Hickman v. Kline, 279 P.2d 662 (Nev. 1955), where the court in effect found that union membership was an enforceable interest as such, and that the member had a "property" right to participate in the determinations and agreements which affected the member's livelihood. The "property" requirement is soundly criticized in Chafee, supro note 103, at 998-1008. Chafee suggests that the concept can always be manipulated, e.g., by viewing the member's contract of membership with the association as "property." Id. at 1001. He therefore proposes that it should be abandoned in favor of a standard with a more realistic criterion for judgment-the personal relation between member and association which Chafee feels warrants judicial protection as such. Id. at 1008-10.

105. Se'e id. at 999-1001.

106. See note 17 supra and accompanying text.

107. See note 18 supra.

108. See Local 104, Int'1 Brotherhood of Boilermakers v. International Brotherhood of Boilermakers, 33 Wash. 2d 1, 203 P.2d 1019 (1949), where the distinction is recognized and discussed. See also Chafee, supra note 103, at 1021; Summers, Legal Limitations on Union Discipline, 64 HARv. L. Rev. 1049, 1050-51 (1951).

109. See Chafee, supra note 103 , at 1021.

110. See Chafee, stopra note 103, at 1021-22; notes 1-7 supra and accompanying text. 
and public interest surrounding the activities of economic associations, and the fairness of their dealings with members or applicants, do not warrant outright suspension of the exhaustion rule as to those associations. Unfairness may lead to severe, even irreparable, injury. But it has been shown that irreparable injury can be avoided without subverting the exhaustion rule. And the public interest is better served by encouraging quasi-public organizations to develop internal means of dealing fairly with their members.

\section{CONCLUSION}

Autonomous, self-disciplining associations are beneficial to the public. The exhaustion of remedies rule serves to promote autonomy and encourage the establishment of fair procedures for maintaining internal discipline. The rule will also prevent an unnecessary expenditure of judicial energy. Moreover, it can be applied strictly, in order to achieve these goals, without prejudicing the rights of disciplined members. Members' rights can be safeguarded by use of a single exception, prohibiting an association from irreparably penalizing a member while it requires him to exhaust his remedies. The rule should be applied purposefully, rather than mechanically, in all other instances. The multiplicity of exceptions which have sprung up unsystematically under the contract rationale, and now threaten to subvert the rule entirely, should therefore be abandoned. 